\title{
EU Engagement in the Arctic: Do the Policy Responses from the Arctic States Recognise the EU as a Legitimate Stakeholder?
}

\author{
Kamrul Hossain \\ Research Director, Northern Institute for Environmental and Minority Law, Arctic Centre, \\ University of Lapland, Rovaniemi, Finland
}

\begin{abstract}
The Arctic states are bound in an institutional relationship by means of their actions through the Arctic Council (AC) - an organisation created by the eight Arctic states. Although a number of its European Union (EU) states are both members and observers in the AC, the EU is not, despite its clear stake in the Arctic, for of a number of reasons. The AC twice postponed the application of the EU in 2013; however, it granted the EU the right to observe the AC meetings as an "observer in principle." In addition to the significant resource and commercial interests of the EU in the Arctic, it assumes a stewardship role in the Arctic. As the leader in combating global climate change, for example, the EU is committed to assuming responsibility for protecting the Arctic environment given that climate change does have a devastating impact in the Arctic. Moreover, the EU is also concerned about its and continental Europe's only indigenous people, the Sámi, a significant proportion of whom live in its Arctic member states of Finland and Sweden. Thus, in recent years, the EU has endorsed a series of policy documents concerning the Arctic. Against the background of this development, this article examines whether the policy responses of the Arctic states with regard to the EU's increased ambition to engage in Arctic matters make it a legitimate actor or stakeholder. The article concludes that even though the Arctic states, as the primary actors, determine the region's governance approach, they see also a general partnership role for the EU with regard to the common goals of knowledge-based responsible governance and sustainable development of the Arctic.
\end{abstract}

Keywords: Arctic Council; Arctic states; European Union; climate change; Sámi; observer status; stakeholder

Received: March 2015; Accepted: July 2015; Published: November 2015

\section{Introduction}

Since the end of past decade, the European Union (EU) has started showing notable interest in the Arctic. While this focus is motivated in part by the resource-oriented and commercial ambitions of the EU in the region, it also - and perhaps more

${ }^{\star}$ Correspondence to: Kamrul Hossain, Research Director, Northern Institute for Environmental and Minority Law, PO Box 122, Arctic Centre, University of Lapland, Fin-96101 Rovaniemi, Finland. Email: kamrul.hossain@ulapland.fi 


\section{K. Hossain}

importantly - reflects a concern over the rapid climate change occurring in the region. As the leader in combating global climate change, the EU is committed to assuming responsibility for protecting the Arctic environment. Climate change will have a devastating impact not only in the Arctic but also globally; for example, melting ice in the Arctic, in particular the Greenlandic ice sheet, is causing sea levels to rise. In addition, the EU is concerned about its and continental Europe's only indigenous people, the Sámi, a significant proportion of whom live in its Arctic member states - Finland and Sweden - and the protection of whose rights falls within the ambit of the EU's policy priorities.

It is in light of these commitments that the EU has developed a policy of its own towards the Arctic. It has concluded bilateral and multilateral cooperation arrangements with a number of states located in the region. While the EU considers the Arctic Council (AC) as the primary intergovernmental body in the region, it has not been admitted as a formal observer in the Council. The AC has twice postponed the EU's application for observer status - in 2009 as well as in 2011. In 2013, however, at the Council's Kiruna meeting, a relatively positive decision was taken concerning the application: although the EU still was not granted official observer status, it was given the right to observe the AC's meetings as an "observer in principle." The most recent AC ministerial meeting, held in Iqaluit, Canada, in April 2015, suggests another 2 years of deferral of its formal observer status to the Council. ${ }^{2}$

Why should the Council be unwilling to formally endorse the EU as an observer? The most obvious answer to the question is that Canada has been unwilling to do so. At the Ministerial Meeting in Kiruna in 2013, Canada was backed by Russia in its efforts to oppose EU observership. ${ }^{3}$ The reason for Canada's reluctance is seemingly the EU's Seal Ban Regulation, ${ }^{4}$ which has aggrieved Canada, whose Inuit population is clearly economically affected by the instrument. However, while Canada, at least seemingly formally, had lifted its opposition at the 2015 AC ministerial meeting, Russia's opposition still led once more to a deferral of the EU becoming a formal observer, ${ }^{5}$ and this is said to be due to the recent diplomatic battles between the EU and Russia. In any case, although the EU is geographically linked to the Arctic (in particular the European Arctic), Canada, Russia, and the United States generally consider it an external player in the region. ${ }^{6}$ In particular, Russia has been traditionally sceptical of any external involvement in regional issues. ${ }^{7}$ Even though the creation of the AC is a product of the post-Cold War era, tensions remain that make Russia cautious despite its gradual engagement in many multilateral forums, such as the Council of Europe and the Organization for Security and Co-operation in Europe, and its recent membership in the WTO. With regard to external engagement in Arctic affairs, especially with respect to the Arctic Ocean, Russia tends to view matters as essentially pertaining to the coastal states only. ${ }^{8}$ As for the European Arctic countries, on an official level they apparently view the EU's engagement as beneficial. However, the bilateral disagreement between the EU and Denmark seems to have created some tension. Denmark's willingness to have an independent Arctic policy, and its distinct position within "the Arctic five" (the Arctic Ocean coastal states) concerning the future management of living resources in the Arctic Ocean 
complicate its relationship with the EU. ${ }^{9}$ In addition, the EU's failed fisheries policy also makes EU's engagement in the AC more complex. Moreover, internal divergences exist among the various EU institutions in their positions towards the Arctic. The European Parliament and the EU Commission, for example, have exhibited incoherence in their positions, which at times makes the EU Arctic policy clumsy.

Nevertheless, a number of EU states are active in the AC both as members and as observers who are to some extent capable of representing EU voices in the AC. However, because of the lack of vertical coherence between the national and EU level, policy-making with respect to the Arctic leads to certain "implementation gaps and opportunity losses." ${ }^{10}$ Although engagement, as an observer for example, would arguably ensure a single unified position for the EU in Arctic matters on behalf of its members, it has been claimed that such engagement would probably overlap with the prevailing obligations of its members already on the Council. ${ }^{11}$ There is a risk of having a multiplicity of voices making things complicated unless a Brusselsbased coordination is established with a view to benefiting both the EU itself and its interested member states from the EU's bilateral dialogues with Arctic states. However, it is important to note that an observer in the AC is entitled to no more than attending AC meetings and participating in projects at the working-group level. Given the minimal scope of this role, one question to be set aside is whether the EU has lost any influence by not being an "official" observer in the AC. Most likely it has not. Rather, it can be said that the EU is capable of influencing the Arctic both as a "semi-internal" and external actor through its various policies, including the use of its market power. The Seal Ban Regulation is one case in which the EU has shown its preparedness to use that power to influence events taking place in the Arctic. Through similar measures, the EU can nudge the Arctic states in the direction it has set for its Arctic policies, one being the protection of the region's fragile ecosystem. ${ }^{12}$ The EU does not necessarily have to be connected to the AC to influence Arctic policy given that actions such as these do not depend on its having any kind of formal status in the AC. For example, the EU's legitimate rights in the Arctic are set by international law regardless of its engagement with the AC. Even though the coastal states have set a "hegemonic role based on sovereign rights and regional presence"13 as the ultimate criterion for regional membership in the AC, the Arctic marine area as a whole is not merely a regional territory whose policies are determined by the states that surround it. The EU role, regardless of its presence in the AC, can be seen as complementary to that of the circumpolar states. Recent decades have seen substantial cooperation arrangements concluded at various levels between the EU and the Arctic states, and this cooperation is being improved on both the multilateral and bilateral levels. In addition, all the Arctic states - as well as many non-Arctic states/actors, such as Germany and the United Kingdom-have independently articulated Arctic policies. In these policies, most of the Arctic states see the EU as a cooperative partner in the promotion of Arctic-related matters with the EU's engagement viewed as complementary to the development taking place in the AC. 


\section{K. Hossain}

Against this background, this article examines whether the policy responses of the Arctic states with regard to the EU's increased ambition to engage in Arctic matters make it a legitimate actor or stakeholder in the Arctic. In this regard, the article particularly explores the questions why and how the EU's Arctic engagement with corresponding policy responses from the Arctic states are set as plausible indicators for its success in becoming a legitimate stakeholder in the Arctic. The analysis is structured in six sections, including an introduction and conclusion. Section 2 gives a brief overview of the prevailing Arctic challenges and the efforts undertaken by the regional actors in addressing them. Section 3 then examines why the EU shows an interest in Arctic affairs when it is not an Arctic actor in the "strict sense." This is followed by a section analysing how the EU has developed an Arctic policy as a semilegitimate Arctic actor. Section 5 goes on to examine the responses of the Arctic states to this development in order to show in the conclusion that policy responses from the Arctic states, except for some speculations from Canada and Russia, are rather affirmative. Both the EU and the Arctic states maintain common objectives in Arctic affairs, and their policies are thus complementary with a view to developing an effective partnership and making the EU a legitimate stakeholder in the Arctic.

\section{Prevailing challenges in the Arctic and the strengthened regional cooperation}

The transformation of the Arctic will be remarkable with the increasingly rapid effects of climate change. The rise in temperature, which is twice as fast compared with the rest of the world, ${ }^{14}$ will lead to melting of sea ice and glaciers ${ }^{15}$ at an ever-faster rate ${ }^{16}$, resulting in an increase in numerous economic activities. As a result, the Arctic will face both new challenges, such as environmental changes, and new opportunities, such as large-scale trans-boundary economic activities. Environmental changes and largescale economic activities are interrelated in the region: the combined effects of the two trends will be the gradual rise of industrial and commercial activities accompanied by extensive developments in infrastructure that will cause significant societal changes. A concomitant, far-reaching, and adverse consequence of the trends is the serious threat they pose to the overall management of the Arctic ecosystems. It is important to note in this regard that the region is home to a significant number of indigenous and coastal communities that will face extreme challenges, for their livelihoods depend on the unique Arctic environment.

As one would expect, it is the Arctic states that are most concerned about the overall changes in the region. Although in the past decades, the Arctic was considered a peripheral region, one not deserving of much international attention, it started to be of concern at the end of 1980s, which marked the beginning of international cooperation among the Arctic states. The first step in that process of international cooperation was the adoption of the Arctic Environmental Protection Strategy (AEPS) in $1991^{17}$ with a view to cooperating in matters of common interest, such as the protection of the Arctic environment throughout the region. However, a significant transformation occurred in this institutional framework between 1996 and 1998 with 
the establishment of the Arctic Council in 1996, a body to promote stronger intergovernmental cooperation among the eight Arctic states. This transformation facilitated the merger of AEPS into the AC policy platform. ${ }^{18}$ The AC's stated mission is to: "promot[e] cooperation, coordination, and interaction among the Arctic States ... on common Arctic issues, in particular [on] issues of sustainable development and environmental protection in the Arctic." The Council today has become the most relevant institution in the circumpolar North. It is an organisation sui generis in that it is not purely intergovernmental but also includes a number of non-state actors, particularly indigenous groups. ${ }^{19}$ The latter actors, who have the status of "permanent participant," have an opportunity to make their voices heard in the decision-making process. ${ }^{20}$ While today the Arctic can be seen as an institutionalised regional political community in which states and non-state actors cooperate within the region towards shared and legitimate objectives with a greater degree of integration, ${ }^{21}$ the AC is neither bound by any treaty nor can it adopt any legally binding treaty by itself. ${ }^{22}$ It falls somewhere between an intergovernmental forum and a regional organisation in its ability to cooperate with actors both within and beyond the region.

\section{Why is the EU interested in the Arctic?}

No doubt, an interest in natural resources is one of the motivating factors for the EU's increasing readiness to engage in Arctic affairs. The EU is particularly dependent upon the oil and natural gas produced in the region, in particular in Norway and in Russia. It has other commercial interests there as well. The EU is the world's largest single market. Not only is it an important trading partner for the Arctic states, but it also cooperates with its northern partners in exploring and establishing new transport routes to facilitate trade and business. For example, the EU has developed the Galileo satellite programme, which, among its other capabilities, enables tracking of transport routes in the Arctic. ${ }^{23}$ Today, the European Parliament is also a full member of the Conference of Parliamentarians of the Arctic Region (CPAR), ${ }^{24}$ which played an important role in establishing the $\mathrm{AC}$ and which actively deals with a number of items on the Arctic agenda, including shipping, education and research, human development, and climate change. Although it is true that there are multiple economic and commercial considerations in the EU's Arctic policy, it is equally true that climate change mitigation and the protection of the Arctic environment are its primary focus, inasmuch as it is committed to the fight against global climate change. On balance, the EU's engagement in the Arctic is based on a paradoxical platform of economic and environmental interests: it seeks to further resource-related and commercial interests on the one hand, and to protect the Arctic environment on the other.

\subsection{Resource and commercial interests}

The EU has significant resource interests in the marine areas of the Arctic waters. Accordingly, the EU maintains close ties with the Arctic states, in particular with its neighbours in the European High North. Shipping and transportation, as well as the supply of living and non-living resources, such as fisheries and oil and gas, play an 


\section{K. Hossain}

important role in the EU's trade relations with the Arctic. In the area of shipping, Europe controls $40 \%$ of the world's merchant fleet, ${ }^{25}$ and European shipping companies have strong interests in safe and expeditious transportation routes that may also save time and energy. Even though it has been observed that development of new Arctic shipping routes will probably be slow, ${ }^{26}$ it should be noted that transport of oil and gas from Arctic Russia and Norway has significantly increased in recent years. ${ }^{27}$ The majority of this maritime traffic is to ports in the EU. In addition, the EU offshore drilling companies, shipping companies engaged in resource transportation, as well as increasing cruise ship and tourism activities are of significance for the EU's Arctic interests.

Concerning living and non-living resources, the EU is highly dependent on the Arctic as far as fisheries and oil and gas resources are concerned. Approximately onethird of the fish caught in the Arctic is consumed in the EU. ${ }^{28}$ The EU cooperates with states that have sovereignty over or jurisdiction in Arctic waters, seeking not only to safeguard fishing opportunities but also to guarantee long-term conservation and optimum utilisation of fishery resources by ensuring that the best scientific evidence available is heeded and proper precautionary approaches are used. ${ }^{29}$ The EU's most important resource interest, however, centres on Arctic hydrocarbons, on which it is highly dependent. ${ }^{30}$ As a region, the Arctic is relatively peaceful and stable compared with the Middle East. Since the EU intends to diversify its energy supply to ensure energy security, it is constantly looking for additional sources of energy. Arctic oil and gas have already proven substantial for the EU. One-fourth of the oil and gas from the Arctic is consumed by the EU. The Barents Sea has been presented as a new oil and gas province that could contribute significantly to the EU energy market. ${ }^{31}$ In its communications with the EU, Norway has stressed two aspects of energy in the High North. ${ }^{32}$ First, the resource potential in the area is significant: the Barents Sea might become Europe's new energy province. Second, Norway is a stable energy supplier in an unstable world, offering secure and predictable conditions for international companies operating on the Norwegian continental shelf.

\subsection{Stewardship}

Combating climate change: Although the resource and commercial interests of the $\mathrm{EU}$ in the Arctic are apparent, in almost all of its policy documents the EU has also highlighted its role as a global leader in combating climate change, which is affecting the Arctic drastically. The EU is thus assuming responsibility for protecting and preserving the unique Arctic environment. The melting of Arctic sea ice as a consequence of a rise in temperatures has proven to have repercussions in other parts of the world, as global sea levels are on the rise. It has been observed that between 2003 and 2008 , melting of the Greenland Ice Sheet contributed to over $40 \%$ of this rise. ${ }^{33}$ Since emission of greenhouse gases contributes to increases in temperature, the EU has incorporated into law its commitment to reduce greenhouse gas emissions by $20 \%$ by 2020 and is committed to a long-term target of reducing emissions by $80-95 \%$ by 2050 . The EU's economic interests in the Arctic thus have to be 
compatible with its climate policy. The Arctic states and the EU have a shared interest in ensuring sustainable utilisation of the Arctic's natural resources on land, in the sea, and on or under the seabed. As part of promoting sustainable management of Arctic natural resources, the EU emphasises the utilisation of new technology and the creation of a knowledge base so that opportunities do not come at the expense of observing the highest environmental standards; in other words, any activity to be initiated must be based upon the best scientific findings available.

Although the EU's gradually increasing energy demand and import of energy from the Arctic runs counter to its emission reduction target, the community nonetheless strongly emphasises the integration of energy and climate policy both internally and externally. The EU aims at decarbonising its energy market by 2050 and by that time increasing the proportion of renewables in its energy mix to $55-97 \% .^{34}$ To achieve this target, the EU will have to substantially decrease its reliance on fossil fuels by acting responsibly for sustainable energy development. As mentioned previously, a large proportion of EU energy imports comes from Russia, whose emission reduction target is more modest than that of the EU. Russia has committed itself to emission reductions of $10-15 \%$ below 1990 levels by 2020 , which means a $30-35 \%$ increase over 2007 levels, and to using $4.5 \%$ renewables in its energy mix by $2020 .{ }^{35}$ The EU is committed to taking effective actions to strike a balance between its internal decarbonisation policy and an external actor's (Russia's) domestic policy based on fossil fuels. It is argued that ecological or environmental constraints on energy policy should be made integral and explicit in the EU-Russia energy dialogue in order to achieve sustainable and climate-friendly energy development in the Arctic. ${ }^{36}$

Protection of the rights of indigenous peoples: Not only does the EU play a major role in climate change, but it is also a major player in international cooperation, norm building, and policy setting where the rights of the indigenous peoples are concerned. The EU policy documents concerning the Arctic repeatedly draw attention to the region's inhabitants, including its significant number of indigenous peoples. The EU also assumes responsibility for its only indigenous community, the Sámi, who inhabit EU territory in the northern part of Finland and Sweden as well as other territories (northern Norway and the northwestern part of Russia in the Kola Peninsula). According to the Treaty on European Union, the Union is founded on, among other principles, the value of respect for human dignity and respect for human rights, including rights of persons belonging to minorities. ${ }^{37}$ The EU aims to develop this value as part of an advanced system of fundamental rights. ${ }^{38}$ In June 2012, the EU adopted the Strategic Framework on Human Rights and Democracy ${ }^{39}$ which emphasises the promotion of human rights across all EU levels. The rights of indigenous peoples with regard to their culture, livelihood, and participation in any decisions that affect them are a core value for EU policy goals as well as for sustainable resource and ecosystem management in the Arctic. While the EU does not have any authority to enforce its policies beyond its territory, its external policies have significant implications for the rights of indigenous peoples. The EU seeks to integrate human rights into all aspects of its external policies prioritising the 


\section{K. Hossain}

promotion and protection of the rights of indigenous peoples across the globe, ${ }^{40}$ particularly with regard to guaranteeing their full participation and free, prior, and informed consent in decision-making processes that affect them. ${ }^{41}$ The EU promotes constitutional norms, such as the promotion of human rights, the rule of law, and democracy in its international relations with other regional actors. ${ }^{42}$

The EU has itself developed a number of documents concerning the protection and promotion of the rights of indigenous peoples. Some of these documents set out the EU's support for the promotion of human rights and democracy in third countries which are not developing countries. ${ }^{43}$ Ever since, the EU has progressed with substantial improvements concerning indigenous peoples' issues. These improvements are reflected both in its human rights policies and in its development policies. In the framework of the European Initiative for Democracy and Human Rights (EIDHR), a project has been established to aid Arctic and sub-Arctic indigenous peoples in pursuing traditional livelihoods, which is viewed as a means to strengthen capacity building in Russia. These relations have been institutionalised to some extent through the CPAR or within the BEAC (Working Group of Indigenous Peoples and the Barents Indigenous Peoples' Office). ${ }^{44}$ It has been argued - particularly in the opinion provided by the Arctic indigenous peoples, the Inuit, for example - that the EU Seal Ban Regulation of 2010 represents a major setback in respecting the value of indigenous culture and cultural rights. The EU nevertheless remains committed to preserving and protecting the rights of the indigenous peoples of the region; to supporting, respecting, and promoting their self-development; to ensuring their effective participation in all stages where their interests are involved; and to enhancing their capabilities to develop free and prior informed consent in matters affecting them. The aforementioned EU documents also recognise the key role played by indigenous peoples in the conservation and sustainable use of natural resources. The recently adopted Council Conclusion reiterates the EU's commitment to increased dialogue with the indigenous peoples of the region in order to explore appropriate ways of ensuring that the representatives of Arctic indigenous peoples are informed and consulted on EU policies that may affect them. ${ }^{45}$ Moreover, the UN Declaration on the Rights of Indigenous Peoples (UNDRIP) contains a set of rules to which the EU has given strong support. ${ }^{46}$

\section{EU Policy towards the Arctic}

In practice, the EU started developing an Arctic policy in March 2008 with "Climate Change and International Security," a document endorsed by the European Commission. ${ }^{47}$ This document highlighted the increasing geopolitical importance of the Arctic resulting mainly from the melting of the polar ice cap, which had increased access to Arctic waters. Prior to that, in 2007, the Commission Communication "An Integrated Maritime Policy for the European Union" cited the importance of the Arctic Ocean. ${ }^{48}$ The Action Plan for Integrated Maritime Policy included preparation of a report by 2008 on Arctic Ocean strategic issues that would lay the foundation for decisions on European interests in the Arctic waters and the EU's response 
in that regard. ${ }^{49}$ Concrete developments in Arctic policy started with a resolution of the European Parliament in October 2008 on Arctic governance, with a proposal for negotiating an international treaty. However, the proposal has attracted harsh criticism from most, if not all, of the Arctic countries. Later, in November, the Commission adopted the Communication "The European Union and the Arctic Region," which deleted the reference to any Arctic treaty solution. There has since been a series of other documents adopted by EU institutions showing the EU's great concern for and stewardship role in the preservation and protection of the Arctic environment. Although EU policy development with regard to the Arctic is ongoing, ${ }^{50}$ three issue areas have been highlighted from the very beginning for the future strategies: protecting and preserving the Arctic in unison with its population, promoting sustainable use of resources, and contributing to enhanced Arctic multilateral governance. ${ }^{51}$ These policy documents suggest that the EU has moved from its position - from its traditional approach of being politically uninvolved in the regionto becoming more engaged, and from seeking a treaty-based solution to supporting the Arctic states' approach to governance with stronger emphasis on the UNCLOS. It has thus certainly entered into an area heavily dominated by sovereign nation states, in particular the Arctic coastal states. Since the Arctic remains dominated by the coastal states, for the EU to have any role to play requires partnership relations with the Arctic states. ${ }^{52}$

In sum, the EU documents set out the goal of sustainable Arctic development where knowledge and responsibility are integrated. As the changing Arctic landscape, new transport routes, and the increased navigation as well as exploration for and exploitation of natural and mineral resources bring new economic life to the region, the EU Arctic policies have addressed the potential risk for the fragile Arctic environment. The EU Arctic policy thus puts an emphasis on cooperation and partnership with the Arctic states through bilateral and institutional means. It highlights the importance of cooperation through legal and institutional mechanisms with a constructive engagement with the Arctic states, indigenous peoples, and other partners to find common solutions to challenges that require an international response. The EU also recognises the legal framework of the Law of the Sea (LOS) Convention and relevant institutions such as the International Maritime Organization (IMO).

\subsection{The EU and the Arctic: the question of legitimacy}

The EU itself is not an Arctic actor in the "strict" geographical sense, nor is it an "officially" designated observer in the main intergovernmental forum on Arctic affairs, the Arctic Council. ${ }^{53}$ The EU has no territorial jurisdiction in the Arctic Ocean, as neither of its Arctic members-Finland and Sweden - has a coastline, but these states are members of the AC. Denmark is a member of the EU, and because of its overseas territories, Greenland and the Faroe Islands, it is also a member of the AC. However, the EU has no territorial jurisdiction over Denmark's Arctic waters since Greenland withdrew from the EU via a referendum held in 1982. It should be noted, however, that Iceland and Norway are committed to many EU regulations through the European Economic Area (EEA) Agreement having as much effect as they 


\section{K. Hossain}

do in EU member states. ${ }^{54}$ Thus, the EU is in one way or another directly linked to five of the eight Arctic states. The EU has several bilateral and regional cooperation agreements with the other three states (Canada, Russia, and the United States) that allow it to engage in various regional matters. The Barents Euro-Arctic Council (BEAC) and the Northern Dimension Policy initiative are important in this regard. Moreover, seven other EU countries are officially designated as observers in the AC. Thus, the EU has geographical as well as political links to the region. In addition, it is connected to the Arctic through history, culture, economy, and science. ${ }^{55}$ The EU can be said to have at least a semi-direct subjectivity in Arctic matters because of its Arctic links and the stewardship role it has assumed in protecting and preserving the unique character of the Arctic environment. Although this sort of analogy may offer some form of recognition where the EU's Arctic competence is concerned, it clearly does not constitute any real institutional presence for the EU as an integrated Arctic actor. The role of the EU in the Arctic has to be examined also in terms of the Union's external policy, through which it influences Arctic matters in its relations with the regional actors by diplomatic means.

\subsection{The EU and the Arctic: developing interregional cooperation?}

The Arctic coastal states' regional presence and sovereignty do not necessarily restrict the EU's "legitimate actorness in Arctic affairs"56 in relation to its capability of influencing Arctic regional affairs. It should be noted that the Arctic is not a geographically self-contained regime. It has to be defined in relational terms that take into consideration the interaction between territorial and non-territorial actors. ${ }^{57}$ The Arctic marine area provides legitimate interests for actors or states other than those regarded as strictly Arctic (e.g. fishing in the high seas or navigation through a country's exclusive economic zone (EEZ)).

While the EU continues to struggle to define its international role and its identity as an international actor, its support for regional integration elsewhere in the world to promote inter-regional cooperation (or bloc-to-bloc diplomacy, rather than traditional state-to-state cooperation) has enhanced its status as an actor in international relations. ${ }^{58}$ Promoting interregional cooperation allows the EU to pursue the larger goal of influence as an international actor. Nevertheless, the EU's foreign policy is relatively new and the constitutional basis for the law governing the EU's international relations is fragmented. ${ }^{59,60}$ The EU has some 20 interregional agreements with other major regional groupings globally. Through such agreements, the EU has been able to influence the region by way of a dual strategy: on the one hand, it promotes the preservation of the regional order with its fundamental characteristics; on the other, it promotes adoption of certain practices, institutional arrangements, or other forms of governance modelled on the European regional governance system, which enhance the EU's global presence in external affairs. ${ }^{61}$ However, the success of a strategy designed to promote EU norms elsewhere depends upon the willingness of the recipient regions to endorse these norms. ${ }^{62}$

As regards the Arctic, the AC cannot be compared with the groupings that exist in Asia, Africa, and Latin America or groupings like G-77, with which the EU promotes 
interregional cooperation. The EU's proximity to the Arctic, as it is inextricably linked to the region by a unique combination of history, geography, economy, and scientific achievements, ${ }^{63}$ allows it to build a stronger regional cohesion. Even though the EU does not have any formal agreement with the AC similar to that underpinning the Asia-Europe Meeting (ASEM), the EU Commission is a member of both the BEAC, a regional cooperation body, and the Northern Dimension, ${ }^{64}$ a common policy of the EU, Iceland, Norway, and the Russian Federation, in which the United States and Canada have observer status. These institutional arrangements would surely provide the desired scope of regional cooperation between the EU, on the one side, and the Arctic actors, on the other. In addition, the EU has significant foreign policy dimensions in economic issues with the Arctic states.

Based on this sort of EU-Arctic engagement, the EU's Arctic policies can be viewed as somewhere between internal and external policies. Generally, the EU's external policies are designed to influence the politics and policies of states or regions beyond the EU in two ways. The impacts of its policies can be driven, on the one hand, by sanctions and/or rewards (what is known as the principle of consequence) or, on the other, through intergovernmental interactions (bargaining or persuasion). ${ }^{65}$ Even though the EU Seal Ban Regulation has had some repercussions, in particular for relations between the EU and Canada, the development of EU relations with the Arctic as a whole, as well as with individual states in the region, shows that the EU relies mostly on its "soft power" resources in the promotion of partnership. Soft power, as opposed to hard power, entails the use of attraction rather than coercion. ${ }^{66}$ In other words, it is a matter of influencing through economic power. ${ }^{67}$ It is based on co-options, in which partners are not forced to align but want to share the same goal, values, and visions due to their perceived attractiveness. ${ }^{68}$ Since interregional cooperation is heavily influenced by geopolitical interests, ${ }^{69}$ soft power can be exercised by interregional cooperation between the two entities (the EU and the Arctic region, the latter represented by the AC) in which the common objectives of promoting fundamental values respecting human rights, the rule of law, and good governance while securing economic interests are balanced. On several occasions, high-profile senior EU officials have emphasised the use of the EU's soft power in external relations, including Arctic affairs. ${ }^{70}$ The most recent EU Council conclusion on the Arctic suggests that the EU may contribute to the work of the AC by influencing Canada. ${ }^{71}$ Specifically, it could tap the current positive momentum in EU-Canada relations to help resolve remaining issues and thereby allow for full implementation of the Kiruna decision regarding the EU's observer status as soon as possible. ${ }^{72}$ It should be noted that after the decision of the WTO dispute resolution panel in May 2014, the EU and Canada have progressed in reaching an agreement on the seal ban issue. That coincided with the final stages of negotiations on the Canada-EU Comprehensive Economic and Trade Agreement (CETA), where partners attempted to resolve pertaining problematic issues, including the seal ban. As a result, a special declaration on the seal trade is expected to be attached to the CETA, where it is likely that the EU will clarify the exemption for traditional indigenous hunting and support Canada in setting up a workable certification and labelling system for seal products 


\section{K. Hossain}

that originate from traditional harvesting. At the same time, Canada has withdrawn its objection to the "full implementation" of the decision made in the 2013 Kiruna Ministerial Meeting on granting the EU observer status in the AC. However, as mentioned, Russia's objection in the Iqaluit meeting held in April 2015, which stemmed from the crisis in Ukraine and the subsequent sanctions that the EU and Russia have imposed on one another, caused another deferral of the EU's official observer status for 2 more years.

\section{Policy responses from the Arctic states}

The AC has not yet recognised the EU as a formal observer. However, the EU can still observe AC meetings as an "observer in principle." In May 2013, the Council revised its rules of procedure, ${ }^{73}$ in fact abolishing the difference in status between formal and ad-hoc observers. Accordingly, all current observers are potentially in the same position as the EU, and observer status can also be revoked by the AC at its discretion. Regardless of the AC's collective acceptance of the EU as an observer, its eight member states - the entire Council - have individually developed Arctic policies, just as the EU has. These policies, despite some variation in approach, do not represent extremely divergent views as regards welcoming the EU to become involved in Arctic matters. Whereas the Nordic countries are far more open to EU engagement, Canada, Russia, and the United States want to keep it to the minimum possible. ${ }^{74}$ All these countries agree on the importance of the EU as an active partner but nonetheless emphasise that the Arctic states should control the proceedings in the AC. ${ }^{75}$ The European Parliament Magazine ${ }^{76}$ published the official statements of some of the Arctic countries maintaining that EU engagement complements the policies of the respective Arctic countries. All the European Arctic states except Russia clearly stated that they want to see the EU as a close partner in Arctic affairs. $^{77,78}$

Amongst the Nordic countries, Finland, Sweden, and Denmark have been supportive of the EU's engagement in the Arctic for obvious reasons (their being EU members). Finland's Strategy for the Arctic Region $2013^{79}$ highlights the importance of the EU formulating a policy towards the Arctic and the reinforcement of its role in the region. One of the key priorities of the Finnish strategy is to support the establishment of the EU's Arctic Information Centre in conjunction with the Arctic Centre of the University of Lapland. ${ }^{80}$ The process of preparing to establish the information centre was begun by the EU Commission at the beginning of 2013. Sweden has fully agreed with the objectives set by the EU to promote an Arctic agenda in its policies. Sweden reaffirmed the EU's effective partnership by the country's involvement in the Northern Dimension along with Iceland, Norway, and Russia; this engagement includes the Arctic as a top-priority area of cooperation. ${ }^{81}$ Norway has set the High North as its number one policy priority ${ }^{82}$ and encourages partnership with the EU in that context. In 2011, Jonas Gahr Støre, the Norwegian Foreign Minister, clearly welcomed the EU's increased engagement in the Arctic and the development of a EU Arctic policy. In his view, the European partners have a 
great deal to contribute as regards research and science, industry, trade, and financial power. ${ }^{83}$ Norway firmly believes that international cooperation has to be developed if the challenges in the Arctic are to be addressed and sustainable management of natural resources ensured, and that the EU has the potential to make a contribution in that regard. ${ }^{84}$ Greenland (even though it does not have a final say in Denmark's foreign policy but has been fully consulted) has taken a similar view and suggested providing for the EU's active participation in the work of the AC. Greenland finds that such participation would provide a more reasoned approach to Arctic issues, such as understanding the importance of protecting traditional lifestyles, the role of marine mammals, and human development issues. At a bilateral level, however, there have been some disagreements between the EU and Denmark (Greenland). Concerns regarding the vote on the ban on trade in polar bear accessories at the Convention on International Trade in Endangered Species (CITES) in Bangkok in 2013, and Denmark's support for the increase in quotas for aboriginal Greenlandic whaling in the International Whaling Commission (IWC) in the same year caused some tensions in its relations with the EU. Denmark even threatened to leave the IWC. The decision was later revised as a number of positive responses have been received in support of aboriginal subsistence whaling in Greenland. ${ }^{85}$ In March 2015, the EU signed a Joint Declaration with the Government of Greenland and the Government of Denmark on relations between the EU and Greenland to further strengthen their relations and cooperation based on broadly shared interests, to the mutual benefit of their peoples, and to endow their mutual relations with a long-term perspective. ${ }^{86}$ As a quasi-independent country, Greenland needs foreign investment for its economic development. The EU can obviously be an important partner and player in the region, one that may contribute to research, transport, energy, climate change, and cooperation in international arenas. ${ }^{87}$ Another member of the AC-Iceland-has expressed its support for EU engagement in the Arctic, citing the mutually beneficial role for both the EU and the Arctic states. It supported the EU's application to become a formal observer in the AC prior to the AC's Kiruna Ministerial Meeting. ${ }^{88}$

In the North American Arctic, Canada's policy towards the Arctic is the top priority. Canada's view is clear and focused squarely on sovereignty, sovereign rights, and jurisdiction in the Arctic through which the Arctic states exercise leadership in the management of the region. It sees a need for strengthening the capacity of the AC. ${ }^{89}$ Although Canada and the EU work together in the area of Arctic science and research as well as through the Northern Dimension policy, to which Canada is an observer, Canada is not content with the EU's position on the issue of the Northwest Passage. The EU, along with the United States and a number of other countries, does not accept Canada's claim of the passage as internal waters. ${ }^{90}$ In addition, Canada's discontent concerning the EU regulation banning trade in seal products brought some unease in the relations between Canada and the EU. Canada maintains the view that the ban on seal products was a political decision that has no basis in fact or in science. ${ }^{91}$ While technically, through an exemption clause, the regulation allows the country's Inuit to place seal products on the EU market, the Inuit hunters 


\section{K. Hossain}

maintain that the ban has destroyed the industry and caused demand for the products to evaporate globally. ${ }^{92}$ The matter apparently disturbed Canada and is the reason why it has vetoed the EU's application for observership in the AC. On the contrary, US Arctic policy, which is a low-priority issue in US foreign policy, took a more conciliatory stance than Canada, ${ }^{93}$ and seeks to cooperate with both Arctic and nonArctic states and actors by developing a strengthened partnership through existing international forums and legal frameworks. To the extent that the partnership seeks to advance shared objectives in order to protect Arctic states' national interests and resources, the United States sees no significant challenges to engagement on the part of external actors, including the EU. ${ }^{94}$ Besides, the United States sees an added value in the EU's engagement for enhanced support for scientific cooperation and, to some extent, building a partnership with the EU on environmental issues. ${ }^{95}$ On the issue of the Northwest Passage, the United States even aligns itself with the position of the EU.

In the case of Russia, the country's ambitious economic projects direct it to cooperate with the EU despite the former's prevailing scepticism. Geographically, Russia accounts for the largest proportion of the Arctic, including almost half of the Arctic Ocean. It is estimated that up to $90 \%$ of the hydrocarbon reserves found on the entire Russian continental shelf lie in the Arctic, with $66.5 \%$ located in its western part in the Barents and Kara Seas. ${ }^{96}$ The demand for Russia's hydrocarbon resources on the EU market is on the rise; it is argued, however, that this demand is probably not as great as Russia's need for the EU energy market. ${ }^{97}$ Russia, thus, has an interest in maintaining the region as an area of international cooperation and in preserving its most important asset as the country's future economic engine. ${ }^{98}$ So far, Russia is the only country in the world with which the EU holds biannual summits, a degree of engagement that is meant to reflect the importance that the EU accords to its relationship with its biggest neighbour in the Arctic. ${ }^{99}$ It is yet to be seen how the EU-Russia business relationship will be impacted by the souring of relations in recent months. The downturn was sparked by Russia's takeover of Crimea and the subsequent political unrest in Ukraine as well as the death of around 300 people in the crash of Malaysian Airlines MH17 over rebel-held Ukraine, allegedly supported by Russia. The situation has further deteriorated with the sanctions imposed upon Russia and countersanctions imposed upon the EU and others by Russia, despite EU companies (e.g. BP, British Petroleum) being concerned about the adverse effects of sanctions on their business with Russia. ${ }^{100}$ The sanctions, related to the oil and gas sector, among others, will prevent future investments by European corporate agents in the Russian fossil fuel sectors directly affecting Arctic-related developments.

Although apparently all eight Arctic states see involvement of the EU in the Arctic as a partnership project to promote an Arctic agenda, they nonetheless have never recognised the EU as a forerunner in Arctic governance, nor have they accepted the EU as a legitimate "stakeholder" in the Arctic. ${ }^{101}$ The implementation of the EU's Arctic policy is possible to the extent the Arctic states consider this relevant to and legitimate for their own interests. In a statement in 2012 in response to a vote by 
the European Parliament's Environmental Committee in favour of a moratorium on Arctic drilling, Per Rune Henriksen, the deputy oil and energy minister of Norway, stated that the EU is "free to argue what it wants ..." but also highlighted that the EU does not have any jurisdiction in the Arctic, and none of its member countries has continental shelf in the region. ${ }^{102}$ According to Henriksen, the clear position of the Norwegian government is that it does not consider the measures by the EU to be of relevance for Norway. ${ }^{103}$ Similarly, the 2014 European Parliament's resolutionthe EU Strategy for the Arctic, ${ }^{104}$ which has proposed the development of a network of Arctic conservation areas and, in particular, the protection of the international sea area around the North Pole outside the economic zones of the coastal states - can only be implemented when the Arctic states, or at least the five coastal states, agree to adopt binding measures. As a result, even though the Arctic countries have clearly recognised EU policies as complementing the strategies of the Arctic states, the EU needs to convince them - in particular the Arctic Five, the five Arctic coastal statesof its rationale for implementing the EU's policies in the region. ${ }^{105}$ However, the Arctic states must recognise the legitimate interests of other states or actors and their role in Arctic governance. Given that all the current formal observers in the AC are potentially in the same position as the EU, it has been argued that they are sitting in an "ejector seat." 106 Unless the Arctic states carefully acknowledge the observers' legitimate roles and interests, only informal pressure can be placed on the AC. In case of any rejection by the AC members of the involvement of the other actors in a matter in which they have a stake, these actors or the group of observers could take up Arctic issues together in another forum outside the AC. In such an extreme case, it is argued, the EU could be in a favourable position to set up such a forum, as it is already very active in regional cooperation on Arctic-related issues, for example, through the BEAC, of which the EU is a member, and the Northern Dimension, a common policy framework in which the EU participates along with Iceland, Norway, and Russia. ${ }^{107}$

\section{Conclusion}

The EU's competence in the Arctic is neither purely internal nor purely external. It is somewhere in between. While the Arctic states do not tend to recognise the EU as a legitimate actor in the region, lacking as it does sovereignty and regional presence, they nevertheless do not deny its importance in the promotion of an Arctic agenda. Given that the Arctic states and the EU are pursuing common objectives-protecting the Arctic environment and its ecosystems and the rights of its inhabitants, including indigenous peoples - whatever competence the EU does have, its policies complement those of the Arctic states. These objectives of EU Arctic policy are perceived as less controversial and understood as being of strategic importance for both the EU and its Arctic partners seeking to establish cooperation. It is also important to note that, in its policy documents, the EU has also clearly recognised the Arctic states' forum - the Arctic Council - as the primary body for dealing with Arctic matters. Although observer status in the AC will not bring any substantial change in the 


\section{K. Hossain}

implementation of the EU's policies in the Arctic, the new developments in observer status suggest that as an "observer in principle" the EU's status is not inferior to that of the other observers. Moreover, regardless of its engagement in the AC, the EU assumes legitimate rights set by international law. Its engagement in the regional affairs through other means, such as by virtue of its membership in the BEAC as well as in the Northern Dimension policy, makes it a relevant regional actor, if not probably a powerful one; yet it may employ its soft power in policy implementation. Although EU policy-making with respect to the Arctic still needs some degree of coordination within the EU's various institutions, with the Arctic players, as well as with other decision makers from areas such as business, economy, science, and civil society, the findings of this article suggest that the EU's ambition to be a relevant stakeholder in the Arctic corresponds thus far with the policy goals set by the Arctic states for developing a partnership with the EU, at least to the extent their formal official statements are concerned.

\section{NOTES}

1. As per new rules of procedure of the Arctic Council, the EU is already an "observer in principle" enjoying virtually the same rights within the Council and its working groups as the other observers. The new rules of procedure have abolished the difference in status between formal and ad-hoc observers. See Arctic Council, "Updated Rules of Procedure," Revised at the 8th Ministerial Meeting, Kiruna, Sweden, May 15, 2013, http://www.arcticcouncil.org/index.php/en/document-archive/category/425-main-documents-from-kirunaministerial-meeting, choose Arctic Council Updated Rules of Procedure (accessed April 19, 2015).

2. Fernando Garcés de los Fayos, "The Outcome of the Ninth Arctic Council Ministerial Meeting," http:/www.europarl.europa.eu/RegData/etudes/ATAG/2015/549036/EXPO_ ATA(2015)549036_EN.pdf (accessed July 1, 2015).

3. Valur Ingimundarson, "Managing a Contest Region: The Arctic Council and the Politics of Arctic Governance," The Polar fournal 4 (2014): 183-98.

4. Regulation (EC) No 1007/2009 of the European Parliament and of the Council, of 16 September 2009 on trade in seal products, Official fournal of the European Union, L 286/36, October 31, 2009, http://ec.europa.eu/food/animal/welfare/trade_seals_products.pdf (accessed April 10, 2015).

5. Fernando Garcés de los Fayos, "The Outcome of the Ninth Arctic Council Ministerial Meeting."

6. Damien Degeorges, "The Arctic - A Region of the Future for the European Union and the World Economy," European issues 263 (2013): 2.

7. Andrey Makarychev, Russia-EU: Competing Logics of Region Building, DGAPanalyse, Deutsche Gesellschaft für Auswärtige Politik e.V., March 13, 2012, https://dgap.org/de/ article/getFullPDF/20801 (accessed April 3, 2012).

8. Hans Corell, "The Arctic: An Opportunity to Cooperate and Demonstrate Statesmanship," Vanderbilt Fournal of Transnational Law 42 (2009): 1065-79.

9. Niord Wegge, "The Emerging Politics of the Arctic Ocean Future Management of the Living Marine Resources," Marine Policy 51 (2015): 335.

10. Steffen Weber, "The Development of an EU Arctic Policy: Interests, Objectives, and Initiatives" in Perceptions and Strategies of Arcticness in sub-Arctic Europe, eds. Andris Spruds and Toms Rostoks (Riga: Latvian Institute of International Affairs, 2014), 73. 
11. Andreas Maurer et al., "The EU as an Arctic Actor? Interests and Governance Challenges," Report on the 3rd Annual Geopolitics in the North-GeoNor-Conference and Joint GeoNor Workshops, Berlin, May 22-24, 2012, 16, http://www.swp-berlin.org/ fileadmin/contents/products/projekt_papiere/Mrr_GeoNor_Conference_Report_1212.pdf (accessed December 13, 2014).

12. Eivid Hoff and Jonas Helseth, "Taking Responsibility," Parliament Magazine Issue 365 (April 4, 2011): 67, http://www.eu-arctic-forum.org/wpcontent/uploads/2011/06/ European_Parliament_Magazin_Special_Arctic.pdf (accessed October 16, 2013).

13. Ingimundarson, "Managing a Contest Region," 184.

14. Arctic Monitoring and Assessment Programme (AMAP), Impact of Warming Arctic, 2004, http://www.amap.no/documents/doc/impacts-of-a-warming-arctic-2004/ (accessed December 13, 2014); and "New Awareness of and Opportunities for UNEP to Address Climate Change in the Arctic: what future for the Arctic?", Global Environmental Ministerial Forum, Nairobi, Kenya (February 18, 2013): 7, http://www.unep.org/gc/gc27/Docs/se/What Future for the Arctic.pdf (accessed October 6, 2015).

15. James J. McKarthy et al., Climate Change 2001: Impacts, Adaptation and Vulnerability, Contribution of Working Group II to the Third Assessment Report of the Intergovernmental Panel on Climate Change (Cambridge: Cambridge University Press, 2011), 26; and Svein Vigeland Rottem and Arild Moe, Climate Change in the North and the Oil Industry, FNI Report 9/2007 (Lysaker: Fridtjof Nansen Institute, 2007), 2.

16. Lenny Bernstein et al., Climate Change 2007 Synthesis Report. An Assessment of the Intergovernmental Panel on Climate Change, (2007): 30-31, http://www.ipcc.ch/pdf/assessmentreport/ar4/syr/ar4_syr.pdf (accessed December 10, 2014).

17. The AEPS was adopted by the eight Arctic states in 1991 in Rovaniemi, Finland. No clear definition of the region's southernmost boundary was mentioned, however; only states having territories above the Arctic Circle were invited to participate in the process.

18. See Joint Communiqué and Declaration on the Establishment of the Arctic Council (Ottawa Declaration) (1996), 35 I.L.M. 1382, http://arctic-council.org/filearchive/Declaration on the Establishment of the Arctic Council-1.pdf, http://www.arctic-council.org/index.php/ en/document-archive/category/5-declarations, choose Ottawa Declaration (accessed April $18,2015)$.

19. Sebastian Knecht, "Arctic Regionalism in Theory and Practice: From Cooperation to Integration?" Arctic Yearbook 2013, (2013): 4.

20. Indigenous peoples' organisations have been granted Permanent Participant status in the Arctic Council. The Permanent Participants have full consultation rights in connection with the Council's negotiations and decisions. Permanent Participants represent a unique feature of the Arctic Council, and they make valuable contributions to its activities in all areas. The following organisations are Permanent Participants in the Arctic Council: Arctic Athabaskan Council (AAC), Aleut International Association (AIA), Gwich in Council International (GCI), Inuit Circumpolar Council (ICC), Russian Association of Indigenous Peoples of the North (RAIPON), Saami Council (SC). See Arctic Council, "Permanent Participants," http://www.arctic-council.org/index.php/en/about-us/permanent-participants (accessed April 18, 2015).

21. Knecht, "Arctic Regionalism in Theory and Practice," 15.

22. Ingimundarson, "Managing a Contest Region," 187.

23. Hoff and Helseth, "Taking Responsibility," 70.

24. Ibid., 70.

25. Patrizia Heidegger et al., "What a Difference a Flag Makes - Why Ship Owner's Responsibility to Ensure Sustainable Ship Recycling Needs to Go Beyond Flag State Jurisdiction," Briefing Paper (2015), http://www.shipbreakingplatform.org/shipbrea_wp2011/wp-content/uploads/ 2015/04/FoCBriefing_NGO-Shipbreaking-Platform_-April-2015.pdf (accessed July 1, 2015). 


\section{K. Hossain}

26. SADA, "Strategic Assessment of Development of the Arctic, Strategic Environmental Impact Assessment of Development of the Arctic," in Assessment conducted for the European Union, eds. Adam Stępień, Timo Koivurova, and Paula Kankaanpää (Rovaniemi: University of Lapland, Arctic Centre, 2014), http://arcticinfo.eu/en/sada (accessed December 13, 2014).

27. While in 2012 Norway accounted for about $31 \%$ of all the EU's natural gas imports and $11 \%$ of its crude oil imports, Russia, in 2013 accounted for $39 \%$ of its natural gas imports. See "Energy," Supplier Countries, http://ec.europa.eu/energy/en/node/11 (accessed July 1, 2015).

28. European Commission, "Developing a European Union Policy towards the Arctic Region: Progress Since 2008 and Next Steps," High Representative of the European Union for Foreign Affairs and Security Policy, (2012), http://eeas.europa.eu/arctic_region/docs/join_2012_19. pdf (accessed December 13, 2014).

29. Ibid.

30. The area north of the Arctic Circle holds about $30 \%$ of the world's undiscovered gas and $13 \%$ of the undiscovered oil, and most of these resources are located under less than $500 \mathrm{~m}$ of water. Approximately $84 \%$ of the undiscovered oil and gas occurs in the offshore Arctic, representing about 90 billion barrels of technically recoverable oil. The Eurasian Arctic tends to have more natural gas, the North American side has more oil. About $65 \%$ of the undiscovered oil and only $26 \%$ of the undiscovered natural gas lies in North American Arctic; the rest lies within the European High North and most likely falls within established Russian territory. See Donald L. Gautier et al., "Assessment of Undiscovered Oil and Gas in the Arctic," Science 324 (2009): 1175-9, doi: http://dx.doi.org/10.1126/science. 1169467; see also Nong Hong, "The Energy Factor in the Arctic Dispute: A Pathway to Conflict or Cooperation?” Fournal of World Energy Law $\mathcal{E}$ Business 5 (2012), doi: http://dx. doi.org/10.1093/jwelb/jwr023

31. Halfdan Carstens, "Exploration: The Barents Sea-Discovering a New Oil \& Gas Province ..”OilVoice, March 8, 2012, http://www.oiledge.com/n/Exploration_The_Barents_Sea_ discovering_a_new_oil_gas_province/ff529252.aspx (accessed April 19, 2015).

32. Kristine Offerdal, "Arctic Energy in EU Policy: Arbitrary Interest in the Norwegian High North," Arctic 63 (2010): 30-42.

33. European Commission, "Developing a European Union Policy towards the Arctic Region."

34. Pami Aalto, "From Separate Policies to Dialogue? Natural Gas, Oil and Electricity on the future Agenda of EU-Russia Energy Relations," CEURUS EU-Russia Papers 3 (2012), 6.

35. Ibid., 6.

36. Ibid., 14.

37. Treaty on European Union, Official fournal of the European Union C326 (1992), Art. 2, doi: http://dx.doi.org/10.3000/1977091X.C_2012.326.eng

38. Sergio Vecchi, "European Union-Russian Federation Sustainable Proximity," (2011), http://www.eu-russiacentre.org/wp-content/uploads/2012/03/European-Union-RussianFederation-sustainable-proximity.pdf (accessed April 19, 2015).

39. Council of The European Union, "EU Adopts Strategic Framework on Human Rights and Democracy," Luxemburg 25.6.2012, 11737/12, Presse 285, http://www.Consilium. Europa.Eu/Uedocs/Cms_Data/Docs/Pressdata/En/Foraff/131173.Pdf (accessed April 19, 2015).

40. "EU Statement-United Nations 3rd Committee: Rights of Indigenous Peoples," Summary: 20 October 2014, http://eu-un.europa.eu/articles/en/article_15604_en.htm (accessed July 1, 2015).

41. Joint statement by the Council and the representatives of the governments of the member states meeting with the Council, the European Parliament and the Commission on European Union Development Policy: "The European Consensus" (2006/C 46/01), 24 February 2006 at para. 103. 
42. Ian Manners, "Normative Power Europe: A Contradiction in Terms?" fournal of Common Market Studies 40 (2002): 235-58.

43. In 1998, the European Commission endorsed a working document on support for indigenous peoples in development cooperation. In November of the same year, the European Council adopted a resolution on indigenous peoples within the framework of the development cooperation of the Community and the Member States. See European Council, "European Council Resolution Indigenous Peoples within the Framework of the Development Cooperation of the Community and the Member States," November 30, 1998, http://eeas.europa.eu/human_rights/ip/docs/council_resolution1998_en.pdf (accessed April 19, 2015). In 1999, Council Regulation (EC) No 976/1999 set the foundation for the European Initiative for Democracy and Human Rights (EIDHR), see the joint statement by the Council, Member States, the European Parliament and the European Commission where the Consensus commits the EU "to apply a strengthened approach to mainstreaming" specific cross-cutting issues, including "indigenous peoples," to integrate their concerns at all levels of cooperation, ensuring their full participation and free, prior and informed consent. EU policy on indigenous peoples (2014), http://eeas.europa.eu/ human_rights/ip/index_en.htm (accessed December 16, 2014).

44. Julien Daemers, "The European Union in the Arctic: A Pole Position?" Bruges Regional Integration \& Global Governance Papers 4/2012, 25. (CRIS: United Nations University), http://www.cris.unu.edu/fileadmin/workingpapers/BRIGG_papers/BRIGG_2012_-_4.pdf (accessed September 28, 2015).

45. Council Conclusions on Developing a European Union Policy towards the Arctic Region, Foreign Affairs Council Meeting, Brussels, May 12, 2014, http://www.consilium.europa.eu/ uedocs/cms_data/docs/pressdata/EN/foraff/142554.pdf (accessed April 19, 2015).

46. EU policy on indigenous peoples.

47. Climate Change and International Security, High Representative and the European Commission to the Council, March 14, 2008, S113/08, http:/www.consilium.europa.eu/ ueDocs/cms_Data/docs/pressData/en/reports/99387.pdf (accessed April 19, 2015).

48. European Commission, "Accompanying Document to the Integrated Maritime Policy," An Integrated Maritime Policy for the European Union, Brussels October 10, 2007, SEC (2007) 1278, http://serv.be/sites/default/files/documenten/IMP-004 EN.pdf (accessed April 19, 2015).

49. Ibid., 30.

50. In 2012, the EU adopted a joint communication titled "Developing a European Union Policy towards the Arctic Region: progress since 2008 and next steps"; see High Representative of the European Union for Foreign Affairs and Security Policy, European Commission, "Developing a European Union Policy towards the Arctic Region: Progress since 2008 and Next Steps," (2012), http://eeas.europa.eu/arctic_region/docs/join_2012_ 19.pdf. In May 2014 the EU adopted "Council conclusions on developing a European Union Policy towards the Arctic Region." (accessed December 16, 2014).

51. European Commission, "The European Union and the Arctic Region," Brussels, October 20, 2008, COM (2008) 763 final, http://eeas.europa.eu/arctic_region/docs/com_08_763_ en.pdf (accessed April 19, 2015).

52. See Wegge Njord, "The EU and the Arctic: European Foreign Policy in the Making," Arctic Review on Law and Politics 3 (2012): 6-29, 11.

53. The EU itself has applied to be an observer in the Arctic Council, but its application was turned down in 2009, at the Tromsø Ministerial. Nevertheless an application by the EU Commission on behalf of the EU for observer status in the Arctic Council was prepared, which was co-signed by Vice President Ashton and Commissioner Damanaki and submitted at the 2013 Ministerial. See High Representative of the European Union for Foreign Affairs \& Security Policy, European Commission. European Commission, 
"Developing a European Union Policy towards the Arctic Region: Progress since 2008 and Next Steps," High Representative of the European Union for Foreign Affairs and Security Policy, (2012), http://eeas.europa.eu/arctic_region/docs/join_2012_19.pdf (accessed April 19, 2015). At the Kiruna meeting of the Arctic Council held in May 2013, the EU application was neither rejected nor accepted, but it has been deferred, which means that the EU does not have any formal status in the Arctic Council. However, the EU can observe the Arctic Council meetings until it is denied permission to do so.

54. Degeorges, "The Arctic - A Region of the Future," 2.

55. Joe Borg, "The Arctic: A Matter of Concern to Us All," Paper presented at the Conference "Common Concern for the Arctic," European Commission Speech 08/415, Ilulissat, Greenland, September 9, 2008.

56. Knecht, "Arctic Regionalism in Theory and Practice," 8.

57. Ingimundarson, "Managing a Contest Region," 185.

58. Mary Farrell, "EU Policy towards Other Regions: Policy Learning in the External Promotion of Regional Integration," fournal of European Public Policy 16 (2009): 1165-84.

59. Paul Craig and Gráinne de Burca, EU Law: Text, Cases and Materials (Oxford: Oxford University Press, 2004), 169.

60. The Lisbon Treaty, in effect since January 1, 2009, has not principally changed this although it introduced new external policy institutions to strengthen the EU's foreign policy coordination and consistency. The "project" of creating a common foreign policy is rarely supported by European institutions, with the exception of the European Parliament.

61. Farrell, "EU Policy towards Other Regions," 1170-1.

62. Ibid., 1180.

63. Commission of the European Communities, "The European Union and the Arctic Region,” Brussels, November 20, 2008, COM(2008) 763 final, http://cordis.europa.eu/ documents/documentlibrary/103814591EN6.pdf (accessed April 19, 2015).

64. The 2010 Northern Dimension Ministerial meeting instructed the ND Steering Group "to consider ways to develop the ND Arctic Window without duplicating work within the mandates of the Arctic Council or the Barents Euro-Arctic Council." See European Commission, "Developing a European Union Policy towards the Arctic Region: Progress since 2008 and Next Steps," High Representative of the European Union for Foreign Affairs and Security Policy, (2012), http://eeas.europa.eu/arctic_region/docs/join_2012_19.pdf (accessed April 19, 2015).

65. Frank Schimmelfennig, "Europeanization beyond Europe," Living Reviews in European Governance, Vol. 7, (2012), No. 1, http://edoc.vifapol.de/opus/volltexte/2014/5275/pdf/ lreg_2012_1Color.pdf (accessed September 28, 2015).

66. Kristian L. Nielsen, "EU Soft Power and the Capability-Expectations Gap," fournal of Contemporary European Research 9 (2013): 723-39.

67. Mary Farrell, The EU and Inter-Regional Cooperation: In Search of Global Presence? UNU-CRIS e-Working Papers, W-2004/9, 2004, 6. http://www.cris.unu.edu/fileadmin/workingpapers/WP Farrell.pdf (accessed September 28, 2015).

68. Joseph S. Nye, Soft Power: The Means to Success in World Politics (New York: Public Affairs, 2004), 5.

69. Farrell, The EU and Inter-Regional Cooperation, 5.

70. Nielsen, "EU Soft Power and the Capability," 724.

71. Council conclusions on developing a European Union Policy towards the Arctic Region, Foreign Affairs Council meeting, Brussels, May 12, 2014, http:/www.consilium.europa.eu/ uedocs/cms_data/docs/pressdata/EN/foraff/142554.pdf (accessed April 19, 2015).

72. Nielsen, "EU Soft Power and the Capability." 
73. Arctic Council, "Updated Rules of Procedure," Revised at the 8th Ministerial Meeting, Kiruna, Sweden, May 15, 2013, http://www.arctic-council.org/index.php/en/documentarchive/category/425-main-documents-from-kiruna-ministerial-meeting, choose Arctic Council Updated Rules of Procedure (accessed April 19, 2015).

74. Norway, for example, showed willingness to proactively cooperate and share its competence; Canada, nevertheless, made its impact by challenging the EU notably through its negative stance toward the EU's desire to become a permanent AS observer. See Wegge, "The EU and the Arctic," 28.

75. Ingimundarson, "Managing a Contest Region," 190; and Arctic Council, "Updated Rules of Procedure," Revised at the 8th Ministerial Meeting, Kiruna, Sweden, May 15, 2013, http://www.arctic-council.org/index.php/en/document-archive/category/425-main-documentsfrom-kiruna-ministerial-meeting, choose Arctic Council Updated Rules of Procedure (accessed April 19, 2015).

76. Arctic Policy, "The Parliament Politics," Policy and People Magazine Issue 325, (April 4, 2011), European Parliament, http://www.eu-arctic-forum.org/wp-content/uploads/2011/ 06/European_Parliament_Magazin_Special_Arctic.pdf (accessed April 19, 2015).

77. Valery Konyshev and Alexander Sergunin, "Is Russia a Revisionist Military Power in the Arctic?" Defense \& Security Analysis 30 (2014): 323-35, doi: http://dx.doi.org/10.1080/ 14751798.2014 .948276

78. It should be noted that despite "multilateralist" rhetoric in the EU Arctic policy documents, these documents hardly mention Russia and/or the BEAC, which are considered the important regional players in Arctic cooperation. For this reason, Russia (along with Canada and the United States) has been reluctant to welcome the EU into the Arctic club.

79. Prime Minister's Office, Finland's Strategy for the Arctic Region, Government Resolution on 23 August 2013, Prime Minister's Office Publications 16/2013, http://vnk.fi/documents/10616/ 1093242/J1613_Finland\%E2\%80\%99s + Strategy + for + the + Arctic + Region.pdf/cf80d586895a-4a32-8582-435f60400fd2?version=1.0 (accessed April 19, 2015).

80. Ibid.

81. Ministry for Foreign Affairs, Sweden's Strategy for the Arctic Region, Government Offices of Sweden, 2011, http://www.government.se/content/1/c6/16/78/59/3baa039d.pdf (accessed April 19, 2015).

82. Arctic Policy, "The Parliament Politics," 58.

83. Ibid., 59.

84. Ibid., 59.

85. Kevin McGwin, "Denmark to Remain in IWC," The Arctic fournal, http://arcticjournal. $\mathrm{com} /$ politics/317/denmark-remain-iwc (accessed July 1, 2015).

86. Joint Declaration by the European Union, on the one hand, and the Government of Greenland and the Government of Denmark, on the other, on relations between the European Union and Greenland, March 19, 2015, https:/ec.europa.eu/europeaid/sites/ devco/files/signed-joint-declaration-eu-greenland-denmark_en.pdf (accessed July 1, 2015).

87. Ibid., 68.

88. Ibid., 68.

89. Ibid., 62 .

90. Lasserre Frédéric, The Geopolitics of Arctic Passages and Continental Shelves, Public Sector Digest, November 2011, http://www.ggr.ulaval.ca/fileadmin/ggr/fichiers/profs/Lasserre/articles/ Geopolitics.pdf; and Rob Huebert, "Polar Vision or Tunnel Vision: The Making of Canadian Arctic Waters Policy," Marine Policy 19 (1995): 343-63.

91. Tristin Hopper, "Europe's Unfair Ban on Canadian Seal Products Can Stay to 'Protect Public Morals' WTO Rules," National Post, May 22, 2014, http://news.nationalpost.com/ 2014/05/22/europes-ban-on-canadian-seal-products-can-stay-to-protect-public-morals-wtorules/ (accessed April 19, 2015). 


\section{K. Hossain}

92. Ibid.

93. Piotr Kobza, "Civilian Power Europe in the Arctic: How Far can the European Union go North," EU Diplomacy Paper 01 (2015), https://www.coleurope.eu/system/files_force/ research-paper/edp_2015_1_kobza.pdf?download=1 (accessed April 19, 2015).

94. The White House, The US National Strategy for the Arctic Region (Washington, DC: The White House, 2013).

95. Kobza, "Civilian Power Europe in the Arctic."

96. Katarzyna Zysk, "Russia's Arctic Strategy: Ambitions and Constraints," foint Force Quarterly Issue 57 (2010), http://www.intelros.ru/pdf/JFQ/57/16.pdf (accessed April 19, 2015).

97. Katinka Barysch, Christopher Coker, and Leszek Jesień, The EU-Russia Relations: Turn for Realistic Turnaround (Brussels: Centre for European Studies, 2011), http://martenscentre. eu/publications/eu-russia-relations-time-realistic-turnaround (accessed April 19, 2015).

98. Zysk, "Russia's Arctic Strategy."

99. Barysch, Coker and Jesień, The EU-Russia Relations.

100. Jennifer Rankin, "BP Warns on Russia Sanctions Despite Rosneft Profits," The Guardian July 29, 2014, http://www.theguardian.com/business/2014/jul/29/bp-russia-sanctionsrosneft (accessed April 19, 2015).

101. Juha Käpylä and Harri Mikkola, "The Growing Arctic Interests of Russia, China, the United States and the European Union,” FIIA Briefing Paper 133 (2013): 7.

102. Thomas Nilsen, "Norway: 'EU has no Jurisdiction in the Arctic'," Barents Observer October 3, http://barentsobserver.com/en/energy/norway-eu-has-no-jurisdiction-arctic03-10 (accessed April 19, 2015).

103. Ibid.

104. European Parliament resolution of 12 March 2014 on the EU strategy for the Arctic (2013/ 2595(RSP)), http://www.europarl.europa.eu/sides/getDoc.do?pubRef=-//EP//TEXT + TA + P7-TA-2014-0236+0 + DOC + XML +V0//EN (accessed July 1, 2015).

105. Kalin Ivanov, "The EU and the Arctic: Competing Priorities," Library Briefing, Library of the European Parliament February 4, 2010, http://www.europarl.europa.eu/Reg Data/bibliotheque/briefing/2010/100001/LDM_BRI\%282010\%29100001_REV2_EN.pdf (accessed April 19, 2015).

106. Daemers, "The European Union in the Arctic," 23.

107. Ibid., 23. 